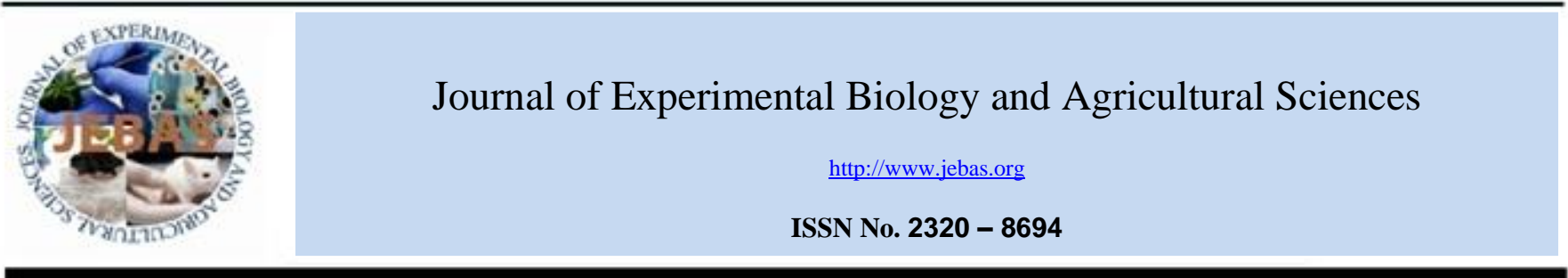

\title{
EFFECT OF BEAN FLOUR ON THE CHEMICAL COMPOSITION, VITAMIN, MINERAL LEVEL AND ORGANOLEPTIC PROPERTIES OF MEAT ROLL
}

\author{
Maksim Rebezov ${ }^{1,2}$, Anuarbek Suychinov ${ }^{3 *}$, Nina Burakovskaya ${ }^{4}$, Maxim Shadrin ${ }^{4}$, \\ Vladimir Ermolaev ${ }^{5}$, Olga Sherstneva ${ }^{2}$, Olga Anichkina $^{2}$, Irina Dolmatova ${ }^{6}$, Tatiana Zaitseva ${ }^{6}$, \\ Larisa Morozova $^{7}$, Ivan Mikolaychik ${ }^{7}$, Olga Neverova ${ }^{8}$
}

${ }^{1}$ V.M. Gorbatov Federal Research Center for Food Systems of Russian Academy of Sciences, Moscow, Russia

${ }^{2}$ K.G. Razumovsky Moscow State University of Technologies and Management (the First Cossack University), Moscow, Russian Federation

${ }^{3}$ Kazakh Research Institute of Processing and Food Industry, Semey, Kazakhstan

${ }^{4}$ Omsk State Technical University, Omsk, Russia

${ }^{5}$ Plekhanov Russian University of Economics, Moscow, Russia

${ }^{6}$ Nosov Magnitogorsk State Technical University, Magnitogorsk, Russian Federation

${ }^{7}$ Kurgan State Agricultural Academy by T.S. Maltsev, Lesnikovo village, Ketovsky district, Kurgan region, Russian Federation

${ }^{8}$ Ural State Agrarian University, Yekaterinburg, Russian Federation

Received - September 26, 2020; Revision - November 13, 2020; Accepted - December 11, 2020

Available Online December 15, 2020

DOI: http://dx.doi.org/10.18006/2020.8(Spl-2-AABAS).S368.S373

\section{KEYWORDS \\ Bean \\ Meat Roll \\ Minced Beef \\ Yield Stress \\ Consistency \\ Vitamin C}

\begin{abstract}
This study was carried out to evaluate the effect of bean flour on the nutritional value and the yield stress of meat rolls. The main components of meat rolls are minced beef, eggs, bread, milk, and beans, but in the current study, the author mixed bean flour with these active ingredients and evaluated the effect of this on the various nutrient parameters of meat rolls. Four samples of meat rolls were prepared, with $0 \%$ to $20 \%$ beans flour. Results of the study found that depending on the concentration of beans, the moisture content, level of carbohydrate, and other nutritive parameters of meat roll have changed significantly due to the specific chemical composition of the bean flour. In terms of vitamin composition, significant changes are observed in the content of vitamin $\mathrm{C}$ and vitamin B1. The addition of bean flour (up to 15\%) to minced rolls gradually increases the yield stress and improving the consistency of the product. According to organoleptic evaluation, the addition of up to $15 \%$ of beans has a positive effect on the consistency of the product due to improved water-binding ability. Results of the study suggesting new data related to the impact of bean flour on the nutritional value and consistency of meat rolls. The developed technology and recipe can be used for large scale meat rolls production.
\end{abstract}

* Corresponding author

E-mail: asuychinov@gmail.com (Anuarbek Suychinov)

Peer review under responsibility of Journal of Experimental Biology and Agricultural Sciences.

Production and Hosting by Horizon Publisher India [HPI] (http://www.horizonpublisherindia.in/).

All rights reserved.
All the articles published by Journal of Experimental Biology and Agricultural Sciences are licensed under a Creative Commons Attribution-NonCommercial 4.0 International License Based on a work at www.jebas.org.

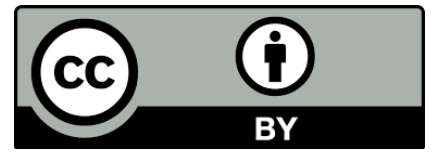




\section{Introduction}

A nutritious diet is an important factor for maintaining the health and productivity of the human. Meat is one of the most important sources of protein, essential amino acids, fatty acids, vitamins, and minerals required for normal body growth. Various by-products of red and white meat are produced under the name of meat products. The shortterm expansion of the meat products production is due to the ease of production, variety of products, increasing employment, and the need for ready-made materials (Devatkal et al., 2004; Nurgazezova et al., 2016; Irshad et al., 2016). Meat products take a special place in the nutrition of modern humans because these are supplying complete proteins containing essential amino acids, vitamins, fatty acids, minerals, and trace elements (Kabulov et al., 2020). One of the types of meat dishes is meat rolls; a meat roll is a product of meat wrapped or filled with some ingredients or a mixture of ingredients. The rolls are made from the front and back hams of the carcass, with or without skin, removing bones and making the meat rolled up like a roll. Mostly these rolls are made up of lamb and beef. These rolls are cooked in boiled-smoked or raw-smoked. Sometimes these are dry, but dense consistency of dark red color muscle tissue (Devatkal et al., 2004; Nurgazezova et al., 2016; Irshad et al., 2016). It is important to combine raw plant materials as an additional ingredient with these rolls. The use of raw plant materials as a protein source is one of the effective methods of human nutritional status regulation, this makes the food enrich with necessary micronutrients and compensate for the deficiency of animal proteins (Nina et al., 2019; Rauf et al., 2020).

In terms of chemical composition, the beans are rich in carbohydrates and protein. High protein content in beans makes this one of the important sources of proteins that help in solving protein deficiencies in the diet of consumers. Using the beans as food and food ingredients is an important strategic and economic policy for the country as a whole. Depending on the variety, beans contain on average $18-25 \%$ protein (Bodoshov, 2015). Further, bean's proteins included all essential amino acids and are almost identical in nutritional value to proteins of animal origin. The mature bean seeds contains 17-33\% protein, $0.8-3.6 \%$ fat, $50-60 \%$ carbohydrates, $5-8 \%$ fiber. The amount of essential amino acids in the bean seed protein varies with the types (\%): arginine (8.1-9.9), histidine (2.3-3.6), lysine (3.4-5.7), methionine (1.7-1.9), tyrosine (2.4-3.0), tryptophan (0.8-1.8), and cystine (1.2-1.6). Also, it has a significant concentration of vitamins (thiamine, riboflavin, niacin, and vitamin E) and various minerals such as potassium, calcium, magnesium, sulfur, phosphorus, iron, copper, manganese. The total amount of ash in bean flour is $2.6-3.7 \%$ (Vavilov, 1986; Spaar, 2000; Gorbatovskaya et al., 2015). The content of non-protein nitrogenous substances (salts of nitric acid, peptides, glutamine, asparagine, and other free amino acids) is up to $0.3 \%$, and the total nitrogen was up to $8.8 \%$ (Arora, 1986).

The development of new kinds of products, the main component of which is meat, requires the most possible use of various kinds of plants in technological processes, including cereals, legumes, and vegetables. Increases the protein concentration in the human diet leading to the development of immunity and increases the resistance against harmful environmental factors (Kaldarbekova et al., 2019). The present experiment aimed to study the effect of the addition of bean flour on the chemical and vitamin composition, organoleptic and structuralmechanical properties of minced meat roll.

\section{Material and Methods}

\subsection{Preparation of minced meat rolls}

At the first stage, mincemeat is being prepared. The beef minced meat is mixed with an egg, onion, and bread crumbs pre-soaked in milk. The obtained minced meat is rolled out in the form of an oval with a thickness of $0.7-1.0 \mathrm{~cm}$. On the rolled out surface, the finely sliced cooked egg, grated cheese, and greens are placed evenly. Then, it is rolled up as a roll and greased with sour cream. The meat roll is baked for 40 minutes at $200{ }^{\circ} \mathrm{C}$ (Table 1).

Table 1 Formulation of meat rolls

\begin{tabular}{|c|c|c|c|c|}
\hline \multirow{2}{*}{ Ingredient } & \multicolumn{4}{|c|}{ Variants $(\%)$} \\
\hline & Variant 1 & Variant 2 & Variant 3 & Variant 4 \\
\hline Beef minced meat & 55 & 45 & 40 & 35 \\
\hline Bean flour & 0 & 10 & 15 & 20 \\
\hline Wheat bread & 4 & 4 & 4 & 4 \\
\hline Milk & 10 & 10 & 10 & 10 \\
\hline Egg & 15 & 15 & 15 & 15 \\
\hline Cheese & 5 & 5 & 5 & 5 \\
\hline Onion & 3.5 & 3.5 & 3.5 & 3.5 \\
\hline Wheat flour & 5 & 5 & 5 & 5 \\
\hline Sour cream & 2 & 2 & 2 & 2 \\
\hline Salt & 0.4 & 0.4 & 0.4 & 0.4 \\
\hline Black pepper & 0.1 & 0.1 & 0.1 & 0.1 \\
\hline
\end{tabular}

Journal of Experimental Biology and Agricultural Sciences http://www.jebas.org 
The evaluation of the meat chemical composition was based on the determination of the constituents includes moisture, fat, ash, protein, and other related indices. The processes were performed with the protocol described by Antipova et al. (2001).

\subsection{Water binding}

The water-binding ability (WBC) of meat roll is based on the exudation of moisture to a filter employing the pressure. The absorption of moisture through the filter is estimated with the spot region on the filter. In unique terms, $0.3 \mathrm{~g}$ of minced-meat samples used to be positioned on the 15 to $20 \mathrm{~mm}$ diameter disk on a Mettler-Toledo digital balance (Mettler Toledo co., Switzerland). This was followed by the meat transferred on an ash-free filter (Munktell Filter AB, Sweden) and positioned on a glass or plexiglass plate. The pattern was protected with the filter before a 1 $\mathrm{kg}$ load was placed on the pinnacle of meat. The used weight was removed after $10 \mathrm{~min}$. Once weight removed, the used filter pulled off, and certain water used to be estimated, as described under (Equations 1 and 2). The filter has been scanned with an Xpress scanner (SAMSUNG Co, Korea) after the contour of the wet spot used to be traced on the filter. The region was calculated using Compas 3D V.10 software program (Okuskhanova et al., 2017).

$X_{1}=(A-8,4 B) \cdot 100 / m_{0}$

$X_{2}=(A-8,4 B) \cdot 100 / A$;

where $X_{1}$ : bound water content, as $\%$ of meat; $X_{2}$ : bound water content, as $\%$ to total water; $B$ : wet spot segment $\left(\mathrm{cm}^{2}\right) ; m_{0}$ : weight (mg); $A$ : total content of moisture (mg).

\subsection{Yield stress determination}

The yield stress of the product was determined by immersing the cone in minced meat in the automatic universal device "Strucrometer" with a software package which is designed by the research and production company "Radius" (Russia). For each sample, the yield stress values are calculated for $\theta_{0}(\mathrm{~Pa})$ with a fixed immersion duration:

$\theta_{0}=K \frac{m}{h^{2}}$

Where $K$ - cone constant, $m$ - mass of the cone and all movable parts, $h$ - cone immersion depth.

Taking into account that the device "Strucrometer" instead of the mass of the cone and all movable parts gives the value of loading in grams, and the depth of the cone immersion in millimeters, respectively, for the convenience of calculations formula (3) is transformed into the following dependence:

$\theta_{0}=K \cdot \frac{P \cdot 9,81 \cdot 10^{3}}{h^{2}}, \mathrm{~Pa}$
Where $P$ - instrument force $(\mathrm{g})$

Accordingly, the cone constant, for a cone of a device having an angle at the apex equal to $\alpha$, is calculated by the formula:

$K=\frac{\cos ^{2}(\alpha / 2)}{\pi \cdot \operatorname{tg}(\alpha / 2)}$,

Where $\alpha$ - cone-apex angle $\left(\alpha=45^{\circ}\right.$ and $\left.\alpha=60^{\circ}\right)$.

The average arithmetic value of yield stress for each variant of investigated samples is calculated by:

$\theta_{0}=\frac{\sum \theta_{i}}{i}$

Where $i$ - number of measurements.

\subsection{Evaluation of organoleptic indicators}

The quality of the uncut and semi cut finished product was assessed first. The quality indexes for the whole product are evaluated in the following sequence:

I. Appearance, colour, and surface condition measured visually by external inspection.

II. Odour of the product was determined by the needle method from the surface (For this special needle was used, it is introduced into the deep thickness of the product and quickly removed and the odour was determined).

III. Consistency of the product was determined by pressing the product with a finger or a pallet.

The color, appearance, and pattern of the cut product as well as the distribution of ingredients were also determined. Further, the smell, aroma, flavor, and juiciness of the product are also well evaluated by paying attention to the absence or presence of foreign smell, the degree of the aroma of spices and flavors. The obtained results are evaluated by a point system or descriptively, for compliance of quality indicators with the requirements of standards and specifications (GOST, 1991).

\subsection{The Statistical analysis}

Statistical analysis was conducted using Statistica version 12.0 (STATISTICA, 2014, USA). The differences between means were evaluated by the ANOVA method. 
Table 2 Chemical composition of meat rolls (\%)

\begin{tabular}{|llllll|}
\hline Variants & Moisture & Protein & Fat & Ash & Carbohydrate \\
\hline Variant 1 control ( $\% \%$ of bean flour) & $71.10 \pm 1.16$ & $15.22 \pm 0.24$ & $6.09 \pm 0.10$ & $0.89 \pm 0.03$ & $6.70 \pm 0.22$ \\
\hline Variant 2 (10\% of bean flour) & $66.20 \pm 0.75^{*}$ & $15.29 \pm 0.41$ & $5.97 \pm 0.15$ & $1.14 \pm 0.03 * * *$ & $11.40 \pm 0.25^{* * *}$ \\
\hline Variant 3 (15\% of bean flour) & $63.72 \pm 1.54^{* *}$ & $15.33 \pm 0.39$ & $5.94 \pm 0.16$ & $1.27 \pm 0.04^{* * *}$ & $13.75 \pm 0.49^{* * *}$ \\
\hline Variant 4 (20\% of bean flour) & $61.24 \pm 1.87^{* * *}$ & $15.36 \pm 0.44$ & $5.91 \pm 0.13$ & $1.39 \pm 0.04^{* * *}$ & $16.10 \pm 0.42^{* * *}$ \\
\hline
\end{tabular}

$* P<0.02 ; * * P<0.05 ; * * * P<0.01$

Table 3 Vitamin composition of meat rolls $(\mathrm{mg} / 100 \mathrm{~g})$

\begin{tabular}{|lcccc|}
\hline & & \multicolumn{3}{c}{ Variants } \\
Vitamin & Variant 1 control & Variant 2 & Variant 3 & Variant 4 \\
& $(0 \%$ of bean flour $)$ & $(10 \%$ of bean flour $)$ & $(15 \%$ of bean flour $)$ & $(20 \%$ of bean flour $)$ \\
\hline Vitamin A & $0.057 \pm 0.001$ & $0.058 \pm 0.001$ & $0.059 \pm 0.001$ & $0.059 \pm 0.002$ \\
\hline Vitamin B1 & $0.053 \pm 0.001$ & $0.097 \pm 0.004^{*}$ & $0.119 \pm 0.004^{*}$ & $0.141 \pm 0.002^{*}$ \\
\hline Vitamin B2 & $0.176 \pm 0.003$ & $0.179 \pm 0.004$ & $0.181 \pm 0.004$ & $0.182 \pm 0.005$ \\
\hline Vitamin B6 & $0.238 \pm 0.007$ & $0.291 \pm 0.007^{* *}$ & $0.318 \pm 0.006^{*}$ & $0.344 \pm 0.006^{*}$ \\
\hline Vitamin B12 & $0.130 \pm 0.003$ & $0.127 \pm 0.003$ & $0.131 \pm 0.002$ & $0.130 \pm 0.002$ \\
\hline Vitamin C & $0.130 \pm 0.002$ & $0.580 \pm 0.016^{*}$ & $0.805 \pm 0.020^{*}$ & $1.030 \pm 0.026^{*}$ \\
\hline Vitamin PP & $5.219 \pm 0.160$ & $5.039 \pm 0.067$ & $4.949 \pm 0.103$ & $4.859 \pm 0.140$ \\
\hline
\end{tabular}

$* P<0.001 ; * * P<0.01$

\section{Results and Discussion}

The biochemical profile, bioactive components, and chemical compositions of the prepared roll are presented in Table 2. The composition of water, carbohydrates, and ash significantly varied and depending on the concentration of beans formulation, as a consequence of the chemical composition of bean flour. Thus, the content of carbohydrates in the control sample without beans was $6.70 \%$, but the addition of beans leads to significant increases to $16.10 \%(\mathrm{P}<0.01)$. With a significant increase in carbohydrates and ash, the amount of moisture in the roll is reduced. While in the case of fat and protein, these are not significantly different than the control.

Results of the study suggested a significant change $(\mathrm{P}<0.001)$ in the content of vitamin $\mathrm{C}$ when adding bean flour to mince rolls. Thus, in the case of the absence of beans flours, the content of vitamin $\mathrm{C}$ was $0.130 \mathrm{mg} / 100 \mathrm{~g}$, while the addition of $10 \%$ beans increases this index by almost five times $(0.580 \mathrm{mg} / 100 \mathrm{~g})$. Further, increasing the concentration of bean flour content accordingly increases the vitamin $\mathrm{C}$ content to $0.805 \mathrm{mg} / 100 \mathrm{~g}$ and 1.030 $\mathrm{mg} / 100 \mathrm{~g}$ in variants 3 and 4 respectively. Also, there is a significant increase in the concentration of vitamin B1 (Table 3). Vitamin $\mathrm{C}$ is essential for body metabolism and tissue nutrition. Further, it is a powerful antioxidant and participates in many physiological processes. The presence of vitamin $\mathrm{C}$ is required for the process of collagen production in the body (Rajasulochana \& Krishnamoorthy, 2013; Suychinov et al., 2019). In the case of other tested vitamins, a slight increase was reported in the concentration of vitamin B6, B2, B12, PP, and A, but these are not statistically different than the control without bean flours.

At the next stage, the effect of bean flour on the mineral composition of different variants of meat rolls is analyzed. From the results of the study, it is revealed that adding $20 \%$ of bean flour increases the proportion of magnesium from $16.79 \mathrm{mg} / 100 \mathrm{~g}$ to $32.79 \mathrm{mg} / 100 \mathrm{~g}$, calcium from $41.59 \mathrm{mg} / 100 \mathrm{~g}$ to $65.99 \mathrm{mg} / 100 \mathrm{~g}$, potassium from $235.33 \mathrm{mg} / 100 \mathrm{~g}$ to $387.26 \mathrm{mg} / 100 \mathrm{~g}$ and phosphorus from $157.38 \mathrm{mg} / 100 \mathrm{~g}$ to $212.58 \mathrm{mg} / 100 \mathrm{~g}$ (Table 4). The amount of iron $(\mathrm{P}<0.001)$ is also increased but as compared to control, this was not significantly different while in the case of sodium and sulphur, these two decreases slightly.

The flavour and nutritional value of meat rolls depend mainly on the right ratio of ingredients in the recipe. For example, meat and eggs are the main sources of protein, while vegetable protein is provided by adding beans. Creamy cheese with $34 \%$ fat and sour cream with $10 \%$ fat also played an important role in the fat content of the roll. Carbohydrate composition is formed by adding beans, wheat bread, and wheat flour. Moreover, the addition of cheese not only improves the taste but also enriches with vitamin A, calcium, potassium, and magnesium. 
Table 4 Mineral content and composition of meat rolls (mg/100g)

\begin{tabular}{|ccccc|}
\hline Mineral & \multicolumn{3}{c|}{ Variants } \\
& $\begin{array}{c}\text { Variant 1 control } \\
\text { (0\% of bean flour })\end{array}$ & $\begin{array}{c}\text { Variant } 2 \\
(10 \% \text { of bean flour })\end{array}$ & $\begin{array}{c}\text { Variant 3 } \\
(15 \% \text { of bean flour })\end{array}$ & $\begin{array}{c}\text { Variant } 4 \\
(20 \% \text { of bean flour })\end{array}$ \\
\hline Potassium & $235.33 \pm 5.58$ & $311.33 \pm 6,39^{*}$ & $349.33 \pm 8,24^{*}$ & $387.26 \pm 8,56^{*}$ \\
\hline Calcium & $41.59 \pm 1.36$ & $53.79 \pm 1.60^{* *}$ & $59.89 \pm 1.62^{*}$ & $65.99 \pm 1.80^{*}$ \\
\hline Magnesium & $16.79 \pm 0.62$ & $24.79 \pm 0.60^{*}$ & $28.79 \pm 0.88^{*}$ & $32.79 \pm 1.08^{*}$ \\
\hline Sodium & $72.29 \pm 1.68$ & $70.59 \pm 2.06$ & $69.74 \pm 2.51$ & $68.89 \pm 1.70$ \\
\hline Sulphur & $156.59 \pm 5.33$ & $150.32 \pm 3.85$ & $147.18 \pm 5.07$ & $144.05 \pm 3.23$ \\
\hline Phosphorus & $157.38 \pm 2.95$ & $184.98 \pm 4.62^{* * *}$ & $198.78 \pm 5.81^{* * *}$ & $212.58 \pm 5.29^{*}$ \\
\hline Iron & $1.32 \pm 0.02$ & $1.74 \pm 0.04^{*}$ & $1.96 \pm 0.06^{*}$ & $2.17 \pm 0.06^{*}$ \\
\hline
\end{tabular}

$* P<0.001 ; * * P<0.002 ; * * * P<0.01$

Table 5 Organoleptic evaluation of meat rolls

\begin{tabular}{|ccccc|}
\hline Characteristic & \multicolumn{3}{c|}{ Variants } \\
(0) of bean flour) & Variant 2 \\
(10\% of bean flour) & $\begin{array}{c}\text { Variant 3 } \\
\text { (15\% of bean flour) }\end{array}$ & $\begin{array}{c}\text { Variant } 4 \\
(20 \% \text { of bean flour) }\end{array}$ \\
\hline Appearance & 4.7 & 4.7 & 4.7 & 4.6 \\
\hline Color on cutting place & 4.5 & 4.5 & 4.6 & 4.6 \\
\hline Odour & 4.8 & 4.8 & 4.8 & 4.5 \\
\hline Taste & 4.5 & 4.5 & 4.5 & 4.4 \\
\hline Consistency & 4.3 & 4.4 & 4.4 & 4.2 \\
\hline Averaged score & 4.56 & 4.58 & 4.60 & 4.46 \\
\hline
\end{tabular}

Yield stress characterizes the transformation of the system from the state of rest to the state of the slow movement of one layer relative to another (creeping) without significant destruction of the structure (Sun \& Gunasekaran, 2009; Kakimov et al., 2015; Kakimov et al., 2017). Also, bean flour in the minced meat roll, a gradual increase in yield stress indicators was reported. This might be due to the tight binding between water and dry components of the minced meat system. Further, it was noted that by the addition of $20 \%$ bean flour yield stress reached up to $500 \mathrm{~Pa}$ and the consistency becomes dense. These characteristics are undesirable and not typical for minced compositions. The water-binding capacity (WBC) change pattern shows that the maximum value $(67.5 \%)$ is determined by adding $15 \%$ bean flour to the minced meat recipe (Figure 1). Further increases of bean flours lead to a decrease in the WBC value. This trend is explained by changes in the structure and consistency of the minced meat, increased dry matter content, which leads to compaction of the structure and increased density of the minced meat.

The organoleptic evaluation of the meat rolls indicated that the addition of $20 \%$ bean flour negatively affects various indicators such as consistency, taste, and odour. While a lower concentration of bean flours improved the overall organoleptic performance, it is mainly due to improved consistency. The addition of up to $15 \%$ beans has a positive effect on the consistency by improving the water-binding capacity (Table 5). Excess moisture, remaining on the surface of the minced meat is more tightly bound to the minced meat system due to the presence of bean flour, capable of hydration of water layers.

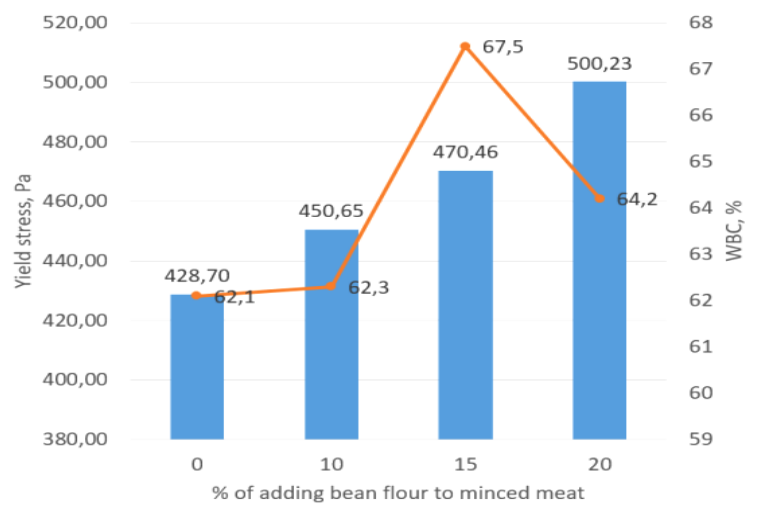

Figure 1 Yield stress and WBC variation of minced meat depending on the content of bean flour 


\section{Conclusions}

Based on the above, the impact of vegetable filler (beans) on the quality characteristics of meat roll is revealed. The addition of up to $15 \%$ of beans in the recipe of meatloaf has a positive effect on nutritional value: increased content of carbohydrates, protein and minerals, vitamin C and B1. However, the bean content of more than $15 \%$ worsens the consistency of the product and organoleptic properties.

\section{Conflict of Interest}

The authors of the present study declare there no conflict of any interest.

\section{References}

Antipova LV, Glotova IA, Rogov IA (2001) Meat and meat products research methods. Moscow: Kolos.

Arora SK (1986) Chemistry and biochemistry of legumes. Translated by K.S. Spectrova. Moscow: Agropromizdat.

Bodoshov AU (2015) Amino acid composition of bean grains grown in Kyrgyzstan. Young Scientist. 24(104):94-96.

Devatkal S, Mendiratta SK, Kondaiah N (2004) Quality characteristics of loaves from buffalo meat, liver and vegetables. Meat science 67(3):377-83.

Gorbatovskaya NA, Muslimov NJ, Dzhumabekova GB (2015) Influence of flour additives of leguminous crops on physical properties of wheat dough. Young Scientist 6(86):141-143.

GOST 9959-91 (1991) Meat products. General conditions for organoleptic evaluation.

Irshad A, Sharma BD, Ahmed SR, Talukder S, Malav OP, Kumar A (2016) Effect of incorporation of calcium lactate on physicochemical, textural, and sensory properties of restructured buffalo meat loaves. Veterinary world 9(2):151-159.

Kabulov B, Kassymov S, Rebezov M, Zinina O, Yu C, Arduvanova F, Peshcherov G, Makarov S, Vasyukova A (2020) Developing the formulation and method of production of meat frankfurters with protein supplement from meat by-products. EurAsian Journal of BioSciences 14(1):213-18.

Kakimov A, Suychinov A, Yessimbekov Z, Okuskhanova E, Kuderinova N, Bakiyeva A, Mayorov A (2017) Meat-bone paste as an ingredient for meat batter, effect on physicochemical properties and amino acid composition. Pakistan Journal of Nutrition 16(10):797-804.
Kakimov A, Yessimbekov Z, Bepeyeva A, Kabulov B, Kakimova Z (2015) Consistency cone penetrometry for food products. Pakistan Journal of Nutrition 14(11):837-840.

Kaldarbekova M, Uzakov Y, Kurmanbekova A, Jetpisbayeva B, Chernukha I (2019) Studying the effect of multicomponent pickle on the quality of cooked and smoked horse meat product. Periodico Tche Quimica 16(33):259-265.

Nina GC, Ogori AF, Ukeyima M, Hleba L, Císarová M, Okuskhanova E, Vlasov S, Batishcheva N, Goncharov A, Shariati MA (2018) Proximate, Mineral and Functional Properties of Tiger Nut Flour Extracted from Different Tiger Nuts Cultivars. The Journal of Microbiology, Biotechnology and Food Sciences 9(3):653-656.

Nurgazezova A, Nurymkhan G, Kassymov S, Kulushtayeva B, Okuskhanova E, Igenbayev A, Issaeva K, Kazhybayeva G (2016) Meat loaf processing technology. Research Journal of Pharmaceutical, Biological and Chemical Sciences 7(6):984-8.

Okuskhanova E, Rebezov M, Yessimbekov Z, Suychinov A, Semenova N, Rebezov Y, Gorelik O, Zinina O (2017) Study of water binding capacity, $\mathrm{pH}$, chemical composition and microstructure of livestock meat and poultry. Annual Research and $\begin{array}{llll}\text { Review in } & \text { Biology }\end{array}$ https://doi.org/10.9734/ARRB/2017/34413.

Rajasulochana P, Krishnamoorthy P (2013) An investigation on the neutraceutical aspects of the Kappaphycus alvarezii. International Journal of Pharmaceutical Research 5(1):25-33.

Rauf A, Bawazeer S, Naseer M, Alhumaydhi FA, Aljohani AS, Habib A, Khan R, Jehan U, Qureshi MN, Khan M, Farooq U (2020) In vitro $\alpha$-glycosidase and urease enzyme inhibition profile of some selected medicinal plants of Pakistan. Natural Product Research 13:1-6.

Spaar D (2000) Cereal legumes. Minsk: Fuainform.

Sun A, Gunasekaran S (2009) Yield stress in foods: Measurements and applications. International Journal of Food Properties 12(1):70-101. https://doi.org/10.1080/10942910802308502.

Suychinov A, Maksimyuk N, Khairullin M, Kulikov D, Konovalov S, Konovalova O, Penkova I, Moldabayeva Z (2019) Vitamins and their role in human body. International Journal of Pharmaceutical Research 11(3):1246-1248.

Vavilov PP (1986) Plant growing. Moscow: Agropromizdat. 